\title{
1 Greek manuscripts in the Library at Wellcome Collection
}

\author{
Owners and cataloguers
}

\author{
Vivian Nutton
}

The Wellcome collection of Greek manuscripts falls into two parts, one created in the eighteenth century, the other largely in the twentieth. They indicate different methods and priorities of collecting as well as the different purposes for which they were bought. Their presence today in the Library at Wellcome Collection owes a great deal also to a small number of individuals, few of whom are remembered today, but without their energy and persistence both parts of the collection would likely have been dispersed years ago.

Anthony Askew, MB, MD Cambridge, FRCP, FRS (1722-74), is a doctor famous today not for his medicine, but for the collection of Greek manuscripts that he amassed during his travels on the continent in the 1740s and later. ${ }^{1}$ At his death in 1774, he owned more than 7,000 volumes, which filled his entire Queen Square house and took 19 days to sell at auction. ${ }^{2}$ His library reputedly contained manuscripts of every Greek author, many obtained from monasteries in the Ottoman Empire. He was collecting at a time when it was possible for a wealthy traveller to acquire Greek manuscripts of all kinds in abundance, particularly from impoverished religious houses - later travellers like Robert Curzon garnered a poorer harvest from similar fields. The part of the collection that ended up in the Library at Wellcome Collection is exclusively medical, but also palaeographically unusual. It contains at least three manuscripts copied in England. MS.MSL.112, a copy of John Zacharias Aktouarios, may well have been written specially for Askew; ${ }^{3}$ MS.MSL.124, also a John Zacharias Aktouarios, was copied from MS 76/43 in Caius College, Cambridge; ${ }^{4}$ and the third, MS.MSL.126, is a partial manuscript of Oribasios copied in Cambridge by a Fellow of St John's College, Robert Wadeson, MD, from a manuscript in his college library, i.e. MS A.6.

1 Munk (1878: 185). For his library, see Fletcher (1902: 219-21).

2 Bibliotheca Askeviana (1785).

3 Bouras-Vallianatos (2015: 307-8).

4 Bouras-Vallianatos (2015: 311-13).

5 Bouras-Vallianatos (2015: 313). 


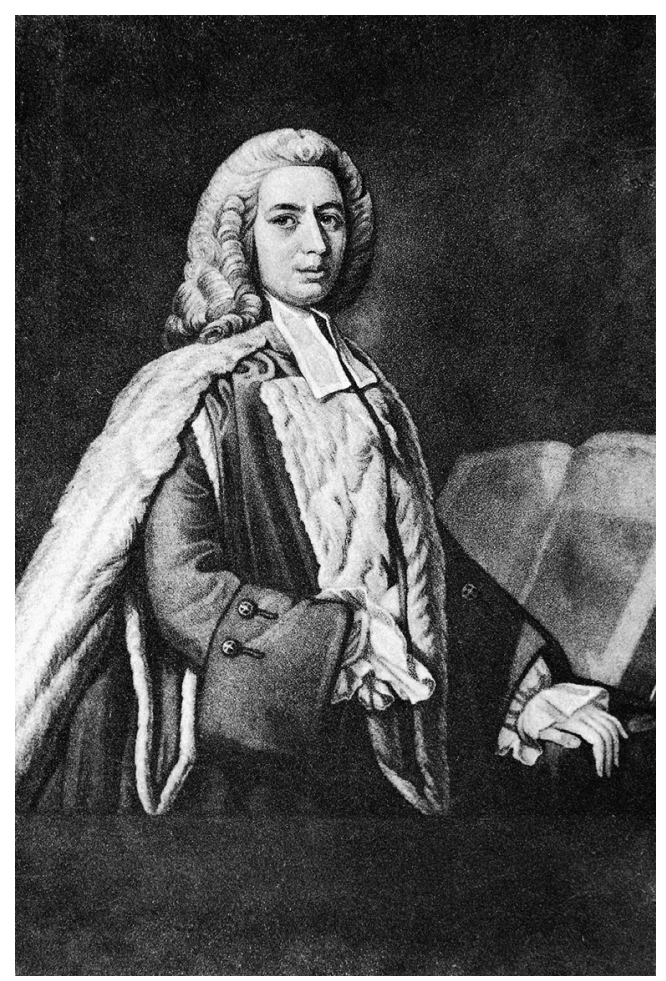

Figure 1.1 Portrait of Anthony Askew, from the photogravure after the picture in Emanuel College, Cambridge.

(C) The Library at Wellcome Collection, London.

Most of Askew's books and manuscripts are today in the British Library, bought by, among others, George III (r. 1760-1820), but many famous collectors joined in the bidding at the first sale and at that of the manuscripts in 1785. One purchaser at the sale of Askew's manuscripts, one of the heroes of this chapter, was James Sims, an Irishman who had moved to London around 1773, and soon established a lucrative practice under the patronage of a celebrated London physician, John Coakley Lettsom (1744-1815). Lettsom is one of the great names in English Georgian medicine, a distinguished physician and the founder of one of the earliest dispensaries, the Aldersgate Dispensary. Lettsom was the moving spirit behind the foundation of The Medical Society of London in 1773, the first successful attempt to bring together respectable practitioners of all kinds who would otherwise have congregated in their respective colleges. His aim was to further medical co-operation, and to enhance medical scholarship by 
learned discussion. ${ }^{6}$ James Sims (1741-1820), who obtained a post at the Aldersgate Dispensary soon after coming to London, joined the Medical Society in 1783 . He was a very clubbable man, and was a leading member of many societies, including the Philanthropic Society and the Humane Society. He quickly made his mark in the Society, becoming its President in 1786 and remaining in office for 22 years. Such a lengthy tenure was not unusual in learned societies of the day: Sir Joseph Banks (1743-1820) held the presidency of the Royal Society for 42 years, Sir Henry Halford (17661844) that of the College of Physicians for 23 years.

Sim's period in office was not always to the satisfaction of the entire membership, for, particularly in his later years, many of the younger members split off to found other similar societies, a few of which are still with us today, most notably what eventually became The Royal Society of Medicine. ${ }^{7}$ One cause of contention was the Society's library. Sims was a great collector, and his private medical library was enormous. In 1802, he persuaded the Society to accept a very unusual arrangement; he made over to the Society all his books and manuscripts in exchange for a payment of $£ 500$, an annuity of $£ 60$ to himself and his wife, and of $£ 90$ a year to the survivor on the death of a spouse. ${ }^{8}$ It was an arrangement that might have seemed a bargain at first to the Society, but became increasingly irksome as Sims grew older and continued in office as President. The library was a remarkable resource - even the Greek manuscripts and classical editions, like Rabelais' edition of the Hippocratic Aphorisms, were still viewed at the time as having practical value. It provided Society members with access to a remarkable collection of information, arguably superior to the libraries of the London colleges because of its broader scope. It housed a wonderful collection of printed Hippocratica, but somewhat less of Galen, reflecting the validity of Hippocrates well into the nineteenth century. ${ }^{9}$ It also included a remarkable number of European university theses from departed universities like Helmstedt and Altdorf. Many of them had been discarded as duplicates in 1788, from the British Library, where most of those that remained were destroyed in the last war.

The library was one of the reasons for the success of the Medical Society, despite competition from such organisations as The Royal Society of Medicine. In 1873 it moved to its present premises in Chandos Street, just behind Cavendish Square, one of London's finest surviving domestic buildings of the early nineteenth century.

6 For the history of the Society, see Hunting (2003). See also Munk (1878: 287); and Lawrence and Macdonald (2003).

7 Munk (1878: 317-18); Hunting (2003: 138-42).

8 Hunting (2003: 24).

9 Nutton (1986-7). 


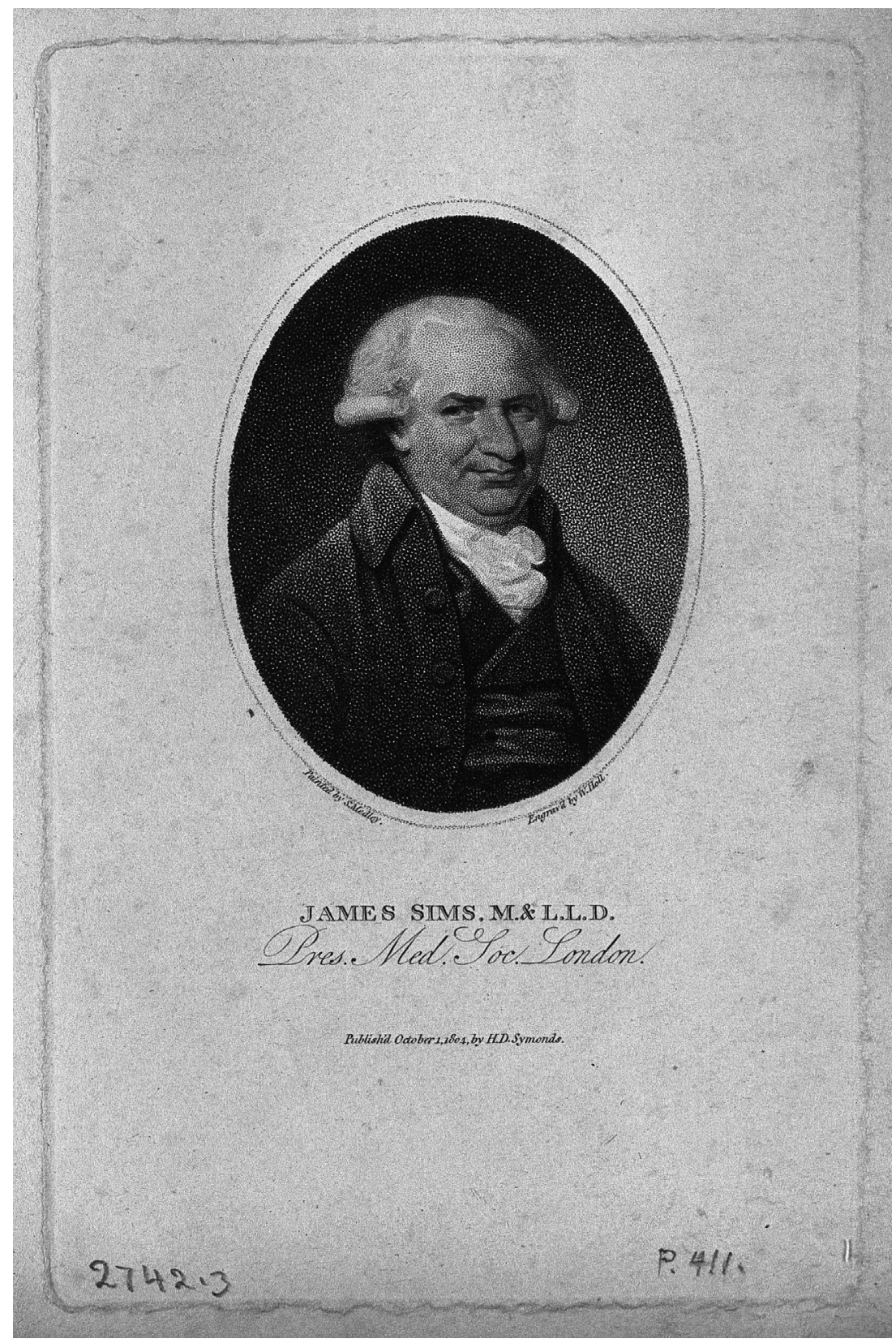

Figure 1.2 James Sims. Stipple engraving by W. Holl, 1804, after S. Medley. (C) The Library at Wellcome Collection, London. 
Seven years later, in 1880, there arrived in London an ambitious young American pharmacist, Henry Solomon Wellcome (1853-1936). ${ }^{10} \mathrm{He}$ had come to join an old friend, Silas Burroughs, who had begun to establish a successful drug business in London. On 30 September 1880, the two concluded an agreement to set up Burroughs Wellcome and Co, which long remained its name in the United States even after the English business had changed its name, confusingly, to The Wellcome Foundation Ltd. Although the business prospered, notably through the introduction of drugs in tablet form, the original tabloids, the personal relationship between the proprietors steadily worsened, and it was only Burroughs' early death in 1895 that prevented the dissolution of the partnership and the break-up of the firm. As it was, Wellcome was now free to run things in his own way. He had two passions, beyond that of money-making: scientific research and the history of medicine. He set up two research laboratories in Beckenham, and there was eventually also a tropical laboratory in Khartoum, all staffed by future eminent scientists, including the Nobel Prize-winner Sir Henry Dale (1875-1968), and avowedly intended to carry out research independent of the company, although in practice the two were closely connected. ${ }^{11}$

Wellcome had begun buying historical objects and books in the 1890s, but it was not until 1896 that he employed anyone to collect and organise his material, probably with a view to an exhibition, and it was perhaps not for another ten years that he began wholesale collecting for his Museum at a rate that increased considerably after the First World War. He bought almost anything to do with the history of medicine, and book dealers were quick to offload their unsellable material to him as job lots. John Symons' history of the Wellcome Library tells many stories of the contortions Wellcome went through to disguise his identity - almost always without success. ${ }^{12}$

But it was the Museum objects that were his main interest - the collection was, at its largest, four times the size of that of the Louvre - and the books and manuscripts were secondary. That is, of course, not to deny that he established what was at the time the largest collection in the world of older medical books, and one not surpassed until the 1980s by the National Library of Medicine as a single medico-historical collection. But, compared with his Latin manuscripts, Wellcome's Greek purchases are few and relatively unimportant; there are only five compared with eleven from the Medical Society, and no Greek manuscripts have been added since the acquisition of the latter. ${ }^{13}$ There are also a few papyri fragments, including the illuminated Johnson Papyrus and the oldest copy of the Hippocratic Oath, MS.5733-5. There is a simple reason for this: the great dispersal of monastic collections had long ended, most major Greek manuscripts were already in official

10 Rhodes James (1994).

11 Tansey (1989).

12 Symons (1993).

13 Bouras-Vallianatos (2015). 


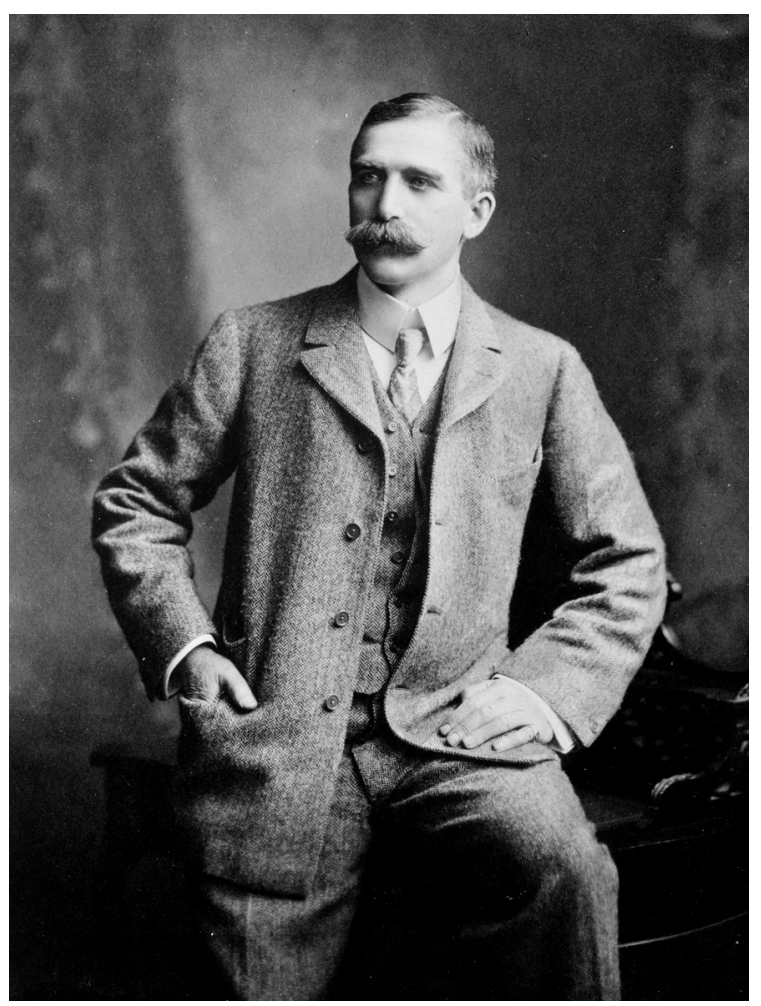

Figure 1.3 Portrait of Sir Henry Wellcome, 1902.

(C) The Library at Wellcome Collection, London.

collections in Italy, Paris, and Berlin, and few came up on the auction market. Where Wellcome did buy large parts of an individual's library, like that of William Morris in 1898, it contained books rather than manuscripts.

Wellcome's vision, to display the history of medicine as part of the universal culture of mankind and to encourage members of the firm to browse among books and objects to gain inspiration for their new discoveries, was wildly optimistic. ${ }^{14}$ His scientists were little interested, and the material was housed miles from the labs in Beckenham or the factory at Dartford. Besides, the amount of material flooding in quickly overwhelmed the curatorial staff of the Museum and Library. Save for a few exhibitions, and some honoured visitors, only a small fraction of the books and manuscripts was put on display during Wellcome's lifetime. When he died in 1936, he 
left the responsibility for his research staff and his collection to his Trustees, but the books and personnel responsible for them still remained within the drug company itself, a situation that still obtained in part when I joined in 1977. This was typical of the man and a company where exactly who owned what was far from clear, and where the boundaries between Wellcome's private enthusiasms and his company were fluid. War only added to the problems. The Wellcome Building on Euston Road, intended for the Museum, had to be adapted suddenly to serve as the headquarters of the company, after it had been forced to move after being bombed out in 1941. (The Trust was located elsewhere and was a tiny organisation.) More seriously, the drug company itself was in grave financial difficulty, and did not begin to be profitable until the mid-1960s. The Trustees, who owned the company, had as a first charge also to pay for the Museum and Library, whose demise was averted only by massive Museum sales. ${ }^{15}$ It required enormous efforts from the Museum Director, E. Ashworth Underwood (1899-1964), and his staff to reopen part of the Museum in 1946 and the Library itself in 1949, albeit in only a small portion of the lavish building that had been planned as part of a scheme that would have covered the whole block between Gordon Street and Gower Street. ${ }^{16}$ Space was at a premium, and continued to be so even after the transfer of the Historical Museum on the second floor and the Tropical Museum in the basement.

The Trust was not the only organisation in difficulties after the war. The Medical Society of London was also faced with the problem about what to do with the older portions of its library, no longer relevant to the interests of most of its members, and occupying space in a most expensive area of London. Its transfer to the Wellcome Library was due to two men, almost forgotten today, but to whom an enormous debt is owed, Noel Poynter and Peter Williams. Noel Poynter (1908-79), who joined the library staff in 1930, became the Librarian in 1954, and then the first Director of the Wellcome Institute from 1964 until 1973. ${ }^{17}$ It was he who had the idea of turning the Library into a truly international research centre, pursuing this vision vigorously and with considerable success. He was an expert networker, particularly among the higher reaches of the London medical scene, and it was he who in 1967 negotiated the deposit of The Medical Society of London material, some 200 manuscripts and 10,000 printed books, in the Library on a 20-year loan. ${ }^{18} \mathrm{He}$ also encouraged, in 1970, The Medical Society of London to sell off duplicates and material that he did not want to go to Toronto to form part of the Hannah Institute for the History of Medicine. According to oral tradition, the Toronto buyer, Jason Hannah, was somewhat miffed to find later that his hoped-for purchase, although extensive,

15 Hall and Bembridge (1986: 22-65); Russell (1986).

16 Symons (1993: 37) shows a projected design for the whole block.

17 Keele (1979); Hall and Bembridge (1986: 131-39).

18 Hunting (2003: 296). 


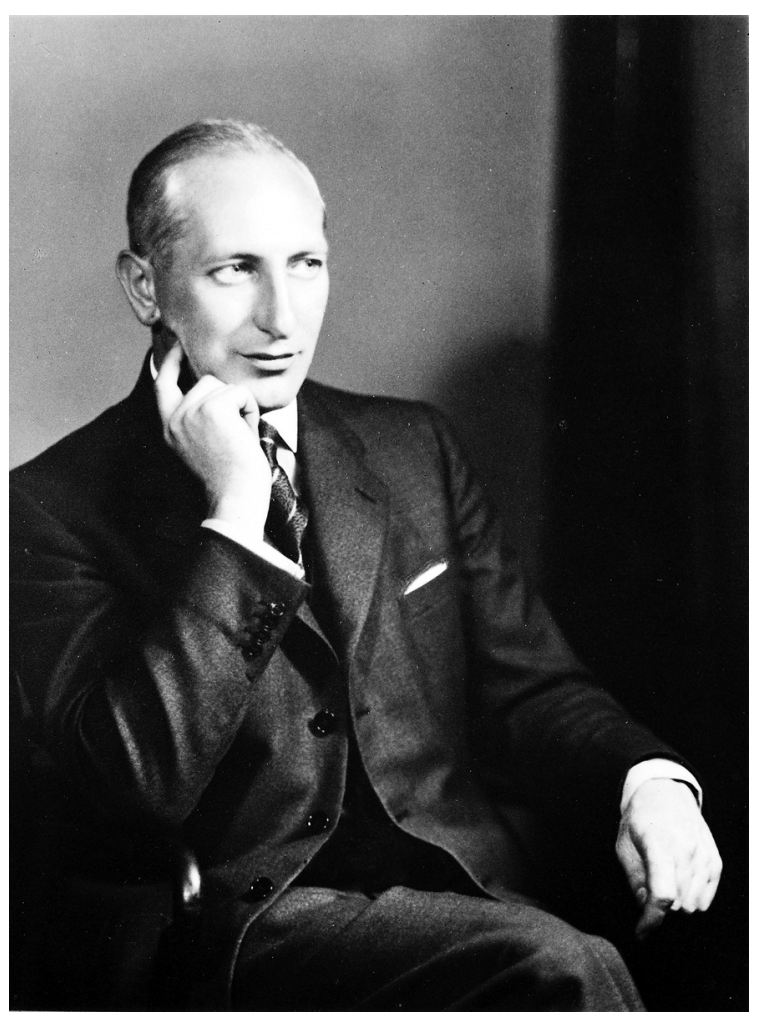

Figure 1.4 Edgar Ashworth Underwood, seated, right hand on cheek.

(C) The Library at Wellcome Collection, London.

was not as great as he had expected. ${ }^{19}$ But while The Medical Society of London loan solved the Society's problems of space, it was a temporary solution - it was after all a loan - and while the Hannah sale allowed Chandos House to be appropriately renovated, the Society's finances continued to deteriorate. The Wellcome Trust was lukewarm at the idea of extending the loan, preferring to purchase the volumes outright. There followed long and at times fraught negotiations on both sides before the Trust, helped by a substantial contribution from the National Heritage Memorial Fund, completed the sale in 1984 at a price of $£ 800,000 .^{20}$

19 It now forms part of the rare book collection in the Thomas Fisher Rare Book Library of the University of Toronto. Poynter played no direct part in the negotiations, but he knew all those involved.

20 Hunting (2003: 300-1). 


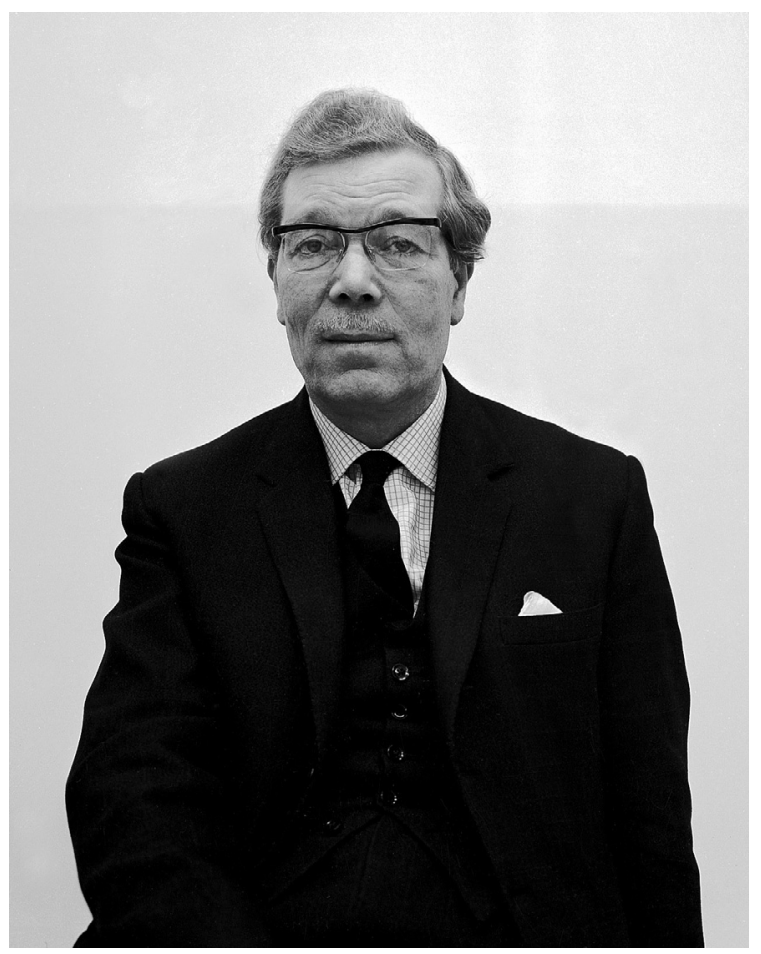

Figure 1.5 Portrait of F. N. L. Poynter.

(C) The Library at Wellcome Collection, London.

But neither deposit nor purchase, nor indeed the Wellcome Institute itself, would have been possible without the support and initiative of Peter Williams (1925-2014), Secretary (later Director) of the Trust from 1965 to 1991 and from 1981-3 also Director of the Institute. ${ }^{21} \mathrm{He}$ and Poynter did not always see eye to eye, and it was probably a good thing that the Euston Road provided a nigh unbridgeable gap between the Wellcome Building and the Trust's offices in Park Square West. But without Williams' backing, it is clear that the Library and Institute, and indeed medical history as a subject, would not have flourished as it did. Williams, whose wife wrote a $\mathrm{PhD}$ thesis on Galvani, came to dominate the Trustees, and his opinions of what medical historians should do carried weight, even if not always to the satisfaction of younger historians. ${ }^{22}$ But he was justly proud of what he achieved

21 Significantly, no obituary appeared in a medical history journal. Obituaries: Cookson (2014); Gordon and Tansey (2014); Watts (2014).

22 Williams (2000). 


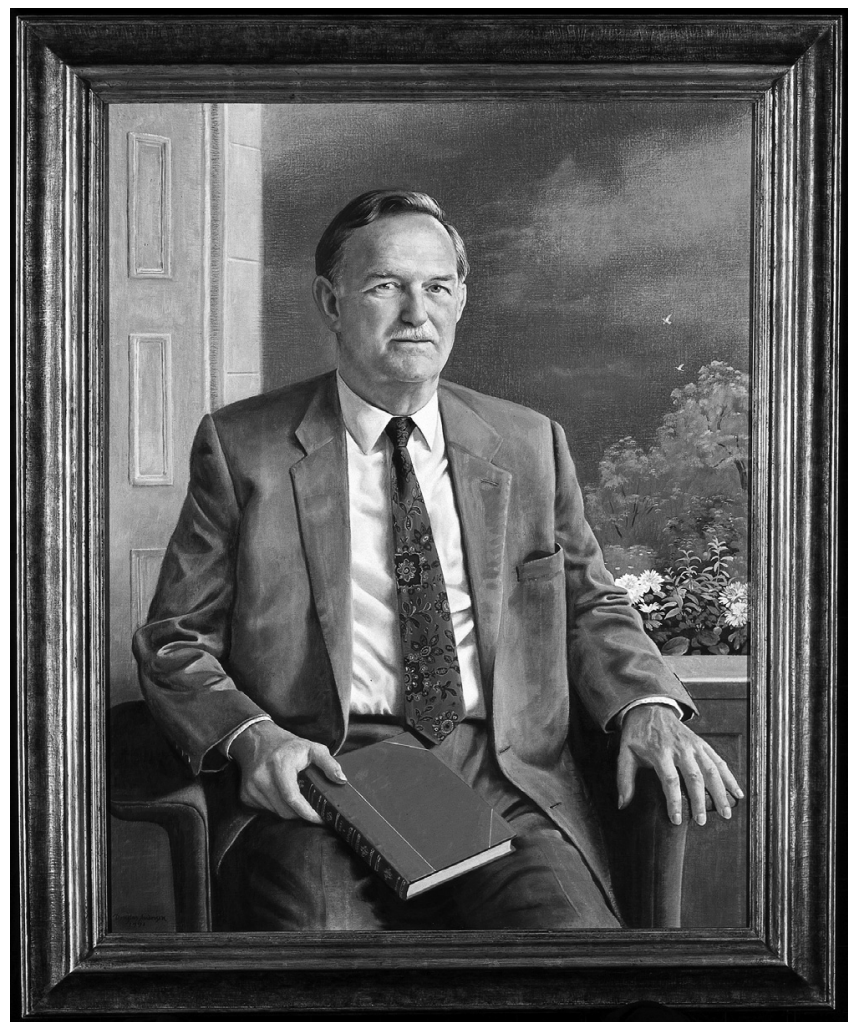

Figure 1.6 Dr Peter Williams (1925-2014), first Director of the Wellcome Trust in his office on the first floor of 1 Park Square West, London, looking on to Regent's Park, and holding a copy of Physic and Philanthropy: A History of the Wellcome Trust 1936-1986 by A. R. Hall and B. A. Bembridge (Cambridge, 1986).

(C) The Library at Wellcome Collection, London.

for the history of medicine, as the Trust's historians acknowledge, and he was generous in his backing for new initiatives. ${ }^{23}$ The relationship between the Trust and the Library has never been entirely harmonious, but one needs only to look around to see the importance of the influence of a Director and Trustees with an interest in medical history.

Since 1984, there have been no new acquisitions of Greek manuscripts. But one did get away: in 2005 the British Library decided not to bid for an interesting Phillipps manuscript of Galen's Therapeutics to Glaucon and 
other texts that had been on loan there for some time, and suggested that the Wellcome should acquire it. It was considered by the Library Committee, who decided not to bid for it. However, the Library and I did make representations to Christie's that, if possible, this should not be sold to go into a bank vault, since I knew of several scholars working on the texts it contained. Our pleas may have had an effect - it may be no coincidence that Christie's head of manuscripts was the wife of the Secretary of the Wellcome Foundation Ltd - and the manuscript is now easily accessible at Yale (Beinecke Rare Book \& Manuscript Library) as MS.1121.

Access to manuscripts also depends on the quality of their catalogues. The catalogue of The Medical Society of London manuscripts was published in 1932 by Warren R. Dawson (1888-1968), an antiquarian greatly interested in Egyptology. ${ }^{24} \mathrm{He}$ was an insurance specialist at Lloyd's, where his wealth allowed him the leisure to pursue a range of antiquarian interests, including acting as a sort of jobbing cataloguer of manuscripts, including those of Lloyd's itself, The Medical Society of London, The Linnean Society and Imperial College. His expertise, it must be said, was in more modern manuscripts and archives, and at times the complexity of many of The Medical Society of London Greek manuscripts defeated him.

His Wellcome counterpart, S. A. J. Moorat, was even longer-lived, working for 50 years in the Library as a cataloguer, before retiring for the second time at the age of 81 in 1973. Moorat, an Oxford graduate, took on the task of producing the catalogue of Western manuscripts as a project after his first retirement in 1946. To complete the first volume of the catalogue by 1962 was a remarkable achievement, even if Moorat had himself been largely responsible for accessioning many of the manuscripts in the hectic period of acquisition in the decade before Wellcome's death. But, like Dawson, Moorat was not a specialist in Greek manuscripts (or for that matter in Medieval Latin), and, although he was helped by some outside scholars, the catalogue was very much an individual effort. Unsurprisingly, mistakes are common, and over the years more than one expert, including Nigel Wilson, was asked to look at the Greek collection and contribute corrections to the catalogue. But like the predecessors of Agamemnon praised by the Roman poet Horace, omnes illacrimabiles urgentur ignotique, their work passes unknown and unmourned, for their comments (as well as many more on the Latin manuscripts) were recorded on cards kept in a white box in the office of the manuscripts curator. But librarians move on and, particularly in the Trust, buildings and offices are redeveloped with remarkable frequency. I managed to keep track of the several moves of the precious box until a dozen years ago, since when it seems to have disappeared. And what, I wonder, has happened to the collection of microfilms of Greek 
manuscripts of Hippocrates and Galen assembled by Iain Lonie and others, and last heard of in a green filing cabinet some 17 years ago? ${ }^{25}$

But it would be churlish to end on this sour note, and without paying tribute to a succession of librarians who have helped to publicise the collection and who have assisted numerous readers with their enquiries. ${ }^{26}$ Indeed, it could well be argued that the non-implementation of these earlier attempts to correct Moorat and Dawson has allowed us to have a new catalogue of the collections, prepared to the highest level of technical expertise. We now know far more today about Wellcome manuscripts than could ever have been hoped for, and certainly far more than was known when I prepared a preliminary survey of the ancient material in The Medical Society of London collection in 1986-7. But that would not have been possible without the contributions of Antony Askew, James Sims, Henry Wellcome, Noel Poynter, and Peter Williams, who bought and preserved the manuscripts that we can use today.

\section{Bibliography}

1785. Bibliotheca Askeviana manu scripta, sive catalogus librorum manuscriptorum Antonii Askew. London: Leigh \& Sotheby.

Bouras-Vallianatos, P. 2015. 'Greek Manuscripts at the Wellcome Library in London: A Descriptive Catalogue', Medical History 59: 275-326.

Cookson, C. 2014. 'Peter Williams, Administrator, 1925-2014', The Financial Times, at www.ft.com/content/214ef158-17fd-11e4-a82d-00144feabdc0 (accessed, 23 May 2019).

Fletcher, W. Y. 1902. English Book Collectors. London: Kegan Paul, Trench, Trübner $\&$ Co.

Gordon, D. and Tansey, T. 2014. 'Peter Williams Obituary', The Guardian, at www. theguardian.com/science/2014/aug/15/peter-williams (accessed, 23 May 2019).

Hall, A. R. and Bembridge, B. A. 1986. Physic and Philanthropy: A History of the Wellcome Trust 1936-1986 (with a foreword by Sir David Steel). Cambridge: Cambridge University Press.

Hunting, P. 2003. The Medical Society of London, 1773-2003. London: The Medical Society of London.

James, T. G. H. 1969. 'W. R. Dawson', The Journal of Egyptian Archaeology 55: 211-14.

Keele, K. D. 1979. 'F. N. L. Poynter', Medical History 23: 372-3.

Larson, F. 2009. An Infinity of Things: How Sir Henry Wellcome Collected the World. Oxford: Oxford University Press.

25 Lest I seem to be picking on my former colleagues, institutional amnesia is common among libraries. The National Library of Medicine had to be alerted only two or three years ago to their collection of microfilms of the Latin Galen assembled by Richard Durling in the 1950s, which were very useful to consult when the Vatican Library was closed, but which had been forgotten once those who had known Durling themselves retired.

26 I mention, honoris causa, from among past librarians, Eric Freeman, Robin Price, John Symons, Richard Palmer, and Richard Aspin. 


\section{Vivian Nutton}

Lawrence, C. and Macdonald, F. A. (eds.). 2003. Sambrook Court: The Letters of J.C. Lettsom at the Medical Society of London. London: The Wellcome Trust Centre for the History of Medicine at University College London.

Munk, W. 1878. The Roll of the Royal College of Physicians of London: Comprising Biographical Sketches of all the Eminent Physicians Whose Names are Recorded in the Annals, Vol. II, 1701 to 1800 [2nd edition]. London: Royal College of Physicians.

Nutton, V. 1986-7. 'The Legacy of Hippocrates: Greek Medicine in the Library of the Medical Society of London', Transactions of the Medical Society of London 103: 21-30.

Rhodes James, R. 1994. Henry Wellcome. London: Hodder \& Stoughton.

Russell, G. 1986. 'The Wellcome Historical Medical Museum's Dispersal of Non-Medical Material, 1936-1983', Museums Journal 86(Supplement): 3-36.

Skinner, G. 1986. 'Sir Henry Wellcome's Museum for the Science of History', Medical History 30: 383-418.

Symons, J. 1993. Wellcome Institute for the History of Medicine: A Short History. London: The Wellcome Trust.

Tansey, E. M. 1989. 'The Wellcome Physiological Research Laboratories 1894-1904: The Home Office, Pharmaceutical Firms, and Animal Experiments', Medical History 33: 1-41.

Watts, G. 2014. 'Peter Orchard Williams', The Lancet 384: 2104.

Williams, B. I. 2000. The Matter of Motion and Galvani’s Frogs. Bletchingdon: Rana. 